\title{
Research on the New Trend of Ideological and Political Education for College Counselors
}

\author{
Bai Yuntao, Li Yingchun* \\ Heihe College, Heihe Heilongjiang 164300
}

Keywords: New normal; College counselors; Ideological and political work; Innovation

\begin{abstract}
Counselors are important implementer of ideological and political work in colleges and universities, which have a great impact on the healthy growth of college students. Under the new normal situation, some new characteristics have appeared in the ideological and political work of college counselors, and some problems have been encountered in the innovation of the ideological and political work of college counselors. It is necessary to clarify the new orientation of the current ideological and political work and promote college counselors to better carry out the ideological and political work.
\end{abstract}

\section{Introduction}

In the new normal situation of higher education, the contents, methods and environment of the ideological and political work of counselors have undergone great changes. It is difficult to meet the needs of students and the development of the country only by relying on the traditional ideological and political education activities. Counselors should study under the new normal situation. The innovation of students'ideological and political work can enhance the effectiveness of Ideological and political work and cultivate more outstanding talents to support the development of the country and the nation..

\section{The New Characteristics of College Counselors' Ideological and Political Work under the New Normal}

The so-called new normal refers to the transformation of China's economic and social development from rapid growth to rapid growth. In May 2014, General Secretary Xi Jinping pointed out during his visit to Henan: "China's development is still in an important strategic opportunity period, we should enhance confidence, proceed from the current stage characteristics of China's economic development, adapt to the new normal, and maintain a normal strategic attitude." This fully shows that in the process of China's development and transformation, the grasp of the development of various undertakings under the new normal will be the focus of work. Under such circumstances, as one of the basic contents of education, the development of Ideological and political work is also facing some new changes. As far as the ideological and political work carried out by college counselors is concerned, its new characteristics are mainly manifested in the following three aspects. 


\subsection{The Methods of Ideological and Political Work Carried Out by College Counselors Tend to be Flexible}

The key goal of College counselors'ideological and political work is to enable students to maintain a positive and good mentality, and to continuously enhance their own strength through the study of knowledge and skills, so as to prepare for the long-term development of the society in the future. Therefore, how to shape the healthy mentality of students is the key work of counselors' Ideological and political work. However, with the maturing of college students'mind, the role of traditional school discipline and class system in guiding and restraining students' thinking and behavior has gradually weakened, and even some extreme ideological and political work methods will not let students form a healthy psychological quality, but will lead to its emergence. Low, rebellious and other negative emotions. Under such circumstances, counselors are more inclined to choose flexible educational methods to indirectly guide and strengthen students'thinking and behavior. The influence and guidance will enable students to have a high degree of psychological identity.

\subsection{The Contents of Ideological and Political Work Carried Out by College Counselors are More Practical.}

Compared with compulsory education and ideological and political work in senior high school, ideological and political work in higher education has higher goals and requirements. Because this stage is the last systematic education before students enter the society, colleges and universities should not only let students master the corresponding theoretical knowledge and practical skills, but also make them have a lot of psychological qualities such as self-confidence, creativity and stress resistance, so as to adapt to the challenging work after entering the society. These high requirements put forward higher requirements for the ideological and political work of College counselors, not only to consider the current physical and mental health of students, but also to take into account the future development needs of students. If the counselor's ideological and political work is confined to the students'immediate learning and growing stage, and neglects the comprehensive consideration of their future development, it will weaken the actual effect of Ideological and political work, which will lead to the students' difficulty in maintaining a scientific and objective attitude when they come into contact with the corresponding work and affect the students. The healthy development of individuals and even the country.

\subsection{The Development of Ideological and Political Work of College Counselors is More Specialized}

The ideological and political work in Colleges and universities is carried out in the face of the special group of College students. This group has the characteristics of professional knowledge and high pursuit of development. This determines that the personnel engaged in Ideological and political work should not only have professional ideological and political theory knowledge, but also have good psychology and management. Sociological knowledge can carry out ideological and political education for students with different personalities, so that students can achieve good development. This situation of Ideological and political work in Colleges and universities determines that it is not easy to carry out the ideological and political work of counselors, which needs to be supported by a large number of professionals with strong politics, professional skills, strict discipline and positive style. Only in this way can the ideological and political quality of college students be improved. 


\section{Problems encountered by College Counselors in Carrying out Ideological and Political Work in the New ormal}

With the increasing demand for outstanding talents in China's economic and social development, how to cultivate more high-quality talents through scientific and systematic higher education to meet the needs of economic and social development has become an important issue for colleges and universities. For colleges and universities, besides professional theoretical knowledge and practical skills training, we should also pay attention to the shaping of students'inner "soft power" so that they can have the spirit of hard struggle and perseverance of indomitable struggle, which depends on the effective development of daily ideological and political work of counselors. As far as the current situation of Ideological and political work carried out by college counselors is concerned, although great progress has been made, there are still many undesirable factors, which restrict the innovation and development of Ideological and political work in Colleges and Universities under the new normal situation.

\subsection{Neglecting the Innovation Ability Building of Counselors' Ideological and Political Work}

The so-called innovative ability of Ideological and political work of counselors refers to the ability of counselors to analyze and solve new contradictions and problems in the process of Ideological and political work by using their own ideas, thinking, methods and models. The construction of innovative ability is a necessary accomplishment for college counselors to adapt to and meet the development requirements of Ideological and political work under the new normal situation. As far as the current ideological and political work of college counselors is concerned, although counselors can properly handle the problems and difficulties encountered in the process of carrying out ideological and political work, and gradually improve students'ideological and political accomplishment, it is still difficult to solve some new situations and problems in a timely and effective manner, resulting in Students are having problems with their mental and psychological conditions. This is directly related to the limited innovation ability of the counselor. In the investigation, it is found that most counselors often pay attention to the routine ideological and political work in carrying out ideological and political work, and lack of research and grasp of the deep-seated problems and laws in the process of carrying out ideological and political work, which makes it difficult to meet the requirements when the work situation changes.

\subsection{Counselors' Ideological and Political Work Innovation Lacks Professional Talents Support}

In the Opinions on Strengthening the Construction of Counselors and Head Teachers in Colleges and Universities issued by the Ministry of Education, it is clearly pointed out that colleges and universities should scientifically and reasonably equip a sufficient number of counselors and head teachers in accordance with the actual needs of work, among which full-time counselors should be equipped at a ratio of 1:200 to ensure that each department is allocated annually. There are a number of full-time counselors in order to ensure the effective development of Ideological and political work. However, as far as the current situation of most college counselors is concerned, the quantity and quality of counselors have not yet met this requirement. Some schools are even equipped with a ratio of 1:700, or even more, which causes counselors in the process of carrying out ideological and political work can not be comprehensive, it is difficult to deepen the effect of Ideological and political work. At the same time, some colleges and universities in the selection of counselors in the process of too broad requirements, resulting in those who lack systematic, professional knowledge of counselors, although able to meet some basic ideological and political 
education content, but seriously restricted the ideological and political work in Colleges and universities to carry out the professionalization, from a long-term point of view, restrain Tied up the ideological and political comprehensive quality of students.

\subsection{Lack of Perfect Method System for Counselors' Ideological Work Innovation}

Ideological and political work as one of the key contents of quality education of College students, its innovation needs to rely on a series of methods to support, especially in the current situation of students'personality highlighted, it is difficult to achieve ideal results by only relying on the traditional single method of Ideological and political education. However, as far as the innovative methods of Ideological and political work are concerned, counselors often adopt the same preaching mode. The disadvantage of this mode is that they neglect the differences among students and cover up the differences of students'ideological and political conditions with universal education. On the one hand, this outmoded working method restricts the innovation of Ideological and political work, on the other hand, it also leads to a big gap between the students'psychological quality and practical ability and the requirements of social development, which is difficult to adapt to the requirements of social development and increases the cost of Ideological and political work.

\section{Innovation of Counselors' Ideological and Political Work.}

In view of the problems encountered by college counselors in the process of carrying out ideological and political work under the new normal, we should solve them through the corresponding content and method innovation, so as to provide an important support for the innovation of Ideological and political work of College counselors. Specifically, the innovation of counselors' Ideological and political work needs to start from the following aspects.

\section{Conclusion}

With the transformation of China's economic and social development from high-speed to medium-high-speed, the ideological and political work of college counselors has entered a new normal. Under such a new situation, counselors should not only have an accurate grasp of the new features of Ideological and political work, but also have a deep understanding and grasp of the problems in the process of carrying out the ideological and political work in Colleges and Universities under the new normal conditions, and seek for them through the corresponding innovation and practical mechanism. Effective solutions to the problem, to achieve the benign development of Ideological and political work counselors, for national and social development to train a large number of high-quality personnel.

\section{References}

[1] Effectiveness and Optimization Strategies of College Counselors under the New Media of Li Aiguo and Deng Lin [J] Journal of Jimei University (Educational Science Edition), 2013 (3): 44-48.

[2] You Xiaolin. Research on the Job Innovation Ability of College Counselors under the New Normal Conditions [J] Education, 2016 (3): 65.

[3] Tang Zhongming. Discussion on the Construction of College Counselors'Job Innovation Ability [J] Yunmeng Journal, 2013 (11): 75-79.

[4] Liu Yijie. Discussion on Gradient Construction of College Counselors'Professionalization, Specialization and Expertization [J]. Examination Weekly, 2014 (A2): 151.

[5] Propaganda Department of the Central Committee of the Communist Party of China. Readings of General Secretary Xi Jinping's Series of Important Speeches [M]. Beijing: People's Publishing House, 2016:288-289 